\title{
The Direct Synthesis of Hydrogen Peroxide over AuPd Nanoparticles: An Investigation into Metal Loading
}

\author{
Joseph Brehm ${ }^{1} \cdot$ Richard J. Lewis $^{1}$ - David J. Morgan ${ }^{1,2} \cdot$ Thomas E. Davies $^{1} \cdot$ Graham J. Hutchings $^{1}$
}

Received: 21 February 2021 / Accepted: 11 April 2021 / Published online: 20 April 2021

(c) The Author(s) 2021

\begin{abstract}
The direct synthesis of $\mathrm{H}_{2} \mathrm{O}_{2}$ from molecular $\mathrm{H}_{2}$ and $\mathrm{O}_{2}$ over AuPd catalysts, supported on $\mathrm{TiO}_{2}$ and prepared via an excess chloride co-impregnation procedure is investigated. The role of Au:Pd ratio on the catalytic activity towards $\mathrm{H}_{2} \mathrm{O}_{2}$ formation and its subsequent degradation is evaluated under conditions that have previously been found to be optimal for the formation of $\mathrm{H}_{2} \mathrm{O}_{2}$. The combination of relatively small nanoparticles, of mixed Pd-oxidation state is shown to correlate with enhanced catalytic performance. Subsequently, a detailed study of catalytic activity towards $\mathrm{H}_{2} \mathrm{O}_{2}$ synthesis as a function of AuPd loading was conducted, with a direct correlation between catalytic activity and metal loading observed.
\end{abstract}

\section{Graphic Abstract}

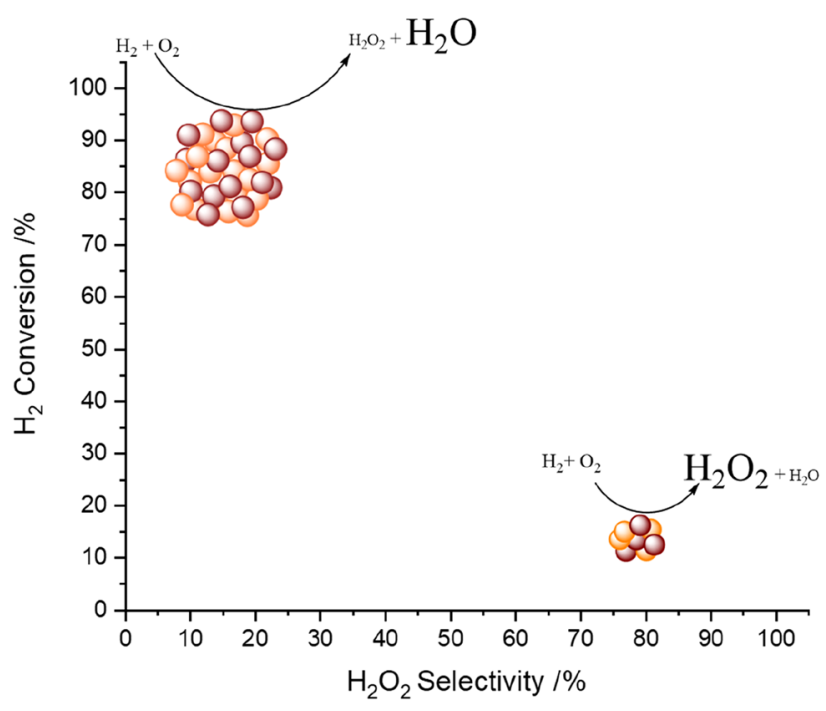

Keywords Gold $\cdot$ Palladium $\cdot$ Hydrogen peroxide $\cdot$ Green chemistry

Joseph Brehm and Richard J. Lewis contributed equally to this work.

Richard J. Lewis

LewisR27@Cardiff.ac.uk

$\triangle$ Graham J. Hutchings

Hutch@Cardiff.ac.uk

1 School of Chemistry, Cardiff University, Main Building, Park Place, Cardiff CF10 3AT, UK

2 HarwellXPS, Research Complex at Harwell (RCaH), Didcot OX11 OFA, UK

\section{Introduction}

Hydrogen peroxide $\left(\mathrm{H}_{2} \mathrm{O}_{2}\right)$ is a powerful, environmentally friendly oxidant with an active oxygen content second only to molecular oxygen. Finding major application in industries where its efficacy as a bleaching agent is required or those that rely on its high active oxygen potential, such as in the chemical synthesis sector, $\mathrm{H}_{2} \mathrm{O}_{2}$ is considered a green alternative to traditional stoichiometric oxidants, such as sodium 
hypochlorite or permanganate, with only water resulting from its application [1].

The direct synthesis of $\mathrm{H}_{2} \mathrm{O}_{2}$ from molecular $\mathrm{H}_{2}$ and $\mathrm{O}_{2}$ would offer an attractive on-site alternative to the current industrial means of $\mathrm{H}_{2} \mathrm{O}_{2}$ production, the anthraquinone oxidation (AO) process. Due to economies of scale $\mathrm{H}_{2} \mathrm{O}_{2}$ production via the $\mathrm{AO}$ process is typically centralized, with $\mathrm{H}_{2} \mathrm{O}_{2}$ often shipped at concentrations far higher than those required by the end user. As such a significant amount of energy, associated with the distillation and concentration of $\mathrm{H}_{2} \mathrm{O}_{2}$ to such high concentrations, prior to shipping is effectively wasted [2,3]. Furthermore, the relative instability of $\mathrm{H}_{2} \mathrm{O}_{2}$, readily decomposing to water in the presence of mild temperatures or weak bases typically necessitates the use of stabilizing agents, with phosphoric acid [4], acetic acid [5] and quinolic acid [6] often used. Finally, there are concerns associated with the carbon-efficiency of the AO process, with the over hydrogenation of the anthraquinone carrier molecule necessitating its periodic replacement. As such an alternative means to produce $\mathrm{H}_{2} \mathrm{O}_{2}$ on-site, at desirable concentrations would have major economic and environmental benefits and to this end the direct synthesis of $\mathrm{H}_{2} \mathrm{O}_{2}$ from molecular $\mathrm{H}_{2}$ and $\mathrm{O}_{2}$, has been extensively studied [1, 3, 7-9].

While Pd-based catalysts have been well reported to offer high activity towards $\mathrm{H}_{2} \mathrm{O}_{2}$ production via the direct route $[1,3,10-14]$, there has been extensive investigation into the alloying of Pd with secondary metals to improve catalytic performance [15-24]. Indeed, the introduction of $\mathrm{Au}$ into supported Pd catalysts has been widely demonstrated to improve catalytic efficacy, with electronic, structural and isolation effects all potential causes for the enhanced performance typically observed in AuPd bi-metallic systems [25-28]. Indeed we have previoulsy reported the ability of $\mathrm{Au}$ to promote the catalytic performance of Pd-based catalysts over a range of reaction conditions [28]. There is general agreement that the enhanced catalytic selectivity observed as a result of AuPd alloying originates, in-part, from the ability of Au to inhibit $\mathrm{O}-\mathrm{O}$ bond scission, and the resulting formation of $\mathrm{H}_{2} \mathrm{O}$. Indeed, several studies have reported that in comparison to Pd-only analogues, AuPd surfaces interact less strongly with $\mathrm{H}_{2} \mathrm{O}_{2}$, with the energetic favourability of $\mathrm{O}-\mathrm{O}$ bond cleavage of $\mathrm{Pd}$ surfaces greatly reduced through the introduction of $\mathrm{Au}$ [29-31].

With these earlier studies in mind and with growing interest in the continual supply of low concentrations of $\mathrm{H}_{2} \mathrm{O}_{2}$ to facilitate chemical transformations [32] we now investigate the effect of metal loading on the ability of AuPd catalysts on the direct synthesis of $\mathrm{H}_{2} \mathrm{O}_{2}$.

\section{Experimental}

\subsection{Catalyst Preparation}

Mono- and bi-metallic $\mathrm{AuPd} / \mathrm{TiO}_{2}$ catalysts have been prepared (on a weight basis) by an excess chloride co-impregnation procedure, based on a methodology previously reported in the literature, which has been shown to improve dispersion of metal species, particularly Au [33]. The procedure to produce $0.5 \% \mathrm{Au}-0.5 \% \mathrm{Pd} / \mathrm{TiO}_{2}(2 \mathrm{~g})$ is outlined below, with a similar methodology utilized for all catalysts.

Aqueous acidified $\mathrm{PdCl}_{2}$ solution $(1.667 \mathrm{~mL}, 0.58 \mathrm{M} \mathrm{HCl}$, $6 \mathrm{mg} \mathrm{mL}{ }^{-1}$, Merck) and aqueous $\mathrm{HAuCl}_{4} \cdot 3 \mathrm{H}_{2} \mathrm{O}$ solution $\left(0.8263 \mathrm{~mL}, 12.25 \mathrm{mg} \mathrm{mL}^{-1}\right.$, Strem Chemicals) were mixed in a $50 \mathrm{~mL}$ round-bottom flask and heated to $65^{\circ} \mathrm{C}$ with stirring $(1000 \mathrm{rpm})$ in a thermostatically controlled oil bath, with total volume fixed to $16 \mathrm{~mL}$ using $\mathrm{H}_{2} \mathrm{O}$ (HPLC grade, Fischer Scientific). Upon reaching $65{ }^{\circ} \mathrm{C}, \mathrm{TiO}_{2}(1.98 \mathrm{~g}$, Degussa, P25) was added over the course of 5 min with constant stirring. The resulting slurry was stirred at $65^{\circ} \mathrm{C}$ for a further $15 \mathrm{~min}$, following this the temperature was raised to $95{ }^{\circ} \mathrm{C}$ for $16 \mathrm{~h}$ to allow for complete evaporation of water. The resulting solid was ground prior to a reductive heat treatment $\left(5 \% \mathrm{H}_{2} / \mathrm{Ar}, 400{ }^{\circ} \mathrm{C}, 4 \mathrm{~h}, 10^{\circ} \mathrm{C} \mathrm{min}^{-1}\right)$. Alternatively, selected samples were subjected to an oxidative heat treatment (flowing air, $400 \mathrm{C}, 3 \mathrm{~h}, 10{ }^{\circ} \mathrm{C} \mathrm{min}^{-1}$ ), with additional samples exposed to a reductive heat treatment (5\% $\mathrm{H}_{2} / \mathrm{Ar}, 200-400{ }^{\circ} \mathrm{C}, 4 \mathrm{~h}, 10{ }^{\circ} \mathrm{C} \mathrm{min}^{-1}$ ).

Surface area measurements of $0.5 \% \mathrm{Au}-0.5 \% \mathrm{Pd} / \mathrm{TiO}_{2}$ and monometallic $\mathrm{Au}$ and $\mathrm{Pd}$ analogues as determined by 5-point $\mathrm{N}_{2}$ adsorption, are reported in Table S.1.

\subsection{Catalyst Testing}

\subsubsection{Note 1}

Reaction conditions used within this study operate below the flammability limits of gaseous mixtures of $\mathrm{H}_{2}$ and $\mathrm{O}_{2}$.

\subsubsection{Note 2}

The conditions used within this work for $\mathrm{H}_{2} \mathrm{O}_{2}$ synthesis and degradation have previously been investigated, with the presence of $\mathrm{CO}_{2}$ as a diluent for reactant gases and a methanol co-solvent identified as key to maintaining high catalytic efficacy towards $\mathrm{H}_{2} \mathrm{O}_{2}$ production [28, 34].

2.2.2.1 Direct Synthesis of $\mathrm{H}_{2} \mathrm{O}_{2}$ from $\mathrm{H}_{2}$ and $\mathrm{O}_{2}$ Hydrogen peroxide synthesis was evaluated using a Parr Instruments stainless steel autoclave with a nominal volume of $100 \mathrm{~mL}$, equipped with a PTFE liner and a maximum working pres- 
sure of 2000 psi. To test each catalyst for $\mathrm{H}_{2} \mathrm{O}_{2}$ synthesis, the autoclave liner was charged with catalyst $(0.01 \mathrm{~g})$ and HPLC standard solvents (5.6 g methanol and $2.9 \mathrm{~g} \mathrm{H}_{2} \mathrm{O}$, both Fischer Scientific). The charged autoclave was then purged three times with $5 \% \mathrm{H}_{2} / \mathrm{CO}_{2}(100 \mathrm{psi})$ before filling with $5 \% \mathrm{H}_{2} / \mathrm{CO}_{2}$ to a pressure of $420 \mathrm{psi}$, followed by the addition of $25 \% \mathrm{O}_{2} / \mathrm{CO}_{2}(160 \mathrm{psi})$. Pressure of $5 \% \mathrm{H}_{2} /$ $\mathrm{CO}_{2}$ and $25 \% \mathrm{O}_{2} / \mathrm{CO}_{2}$ are given as gauge pressures and reactant gasses are not continually supplied. The reaction was conducted at a temperature of $2{ }^{\circ} \mathrm{C}$, for $0.5 \mathrm{~h}$ with stirring $(1200 \mathrm{rpm})$, with the reactor temperature controlled using a HAAKE K50 bath/circulator using an appropriate coolant.

$\mathrm{H}_{2} \mathrm{O}_{2}$ productivity was determined by titrating aliquots of the final solution after reaction with acidified $\mathrm{Ce}\left(\mathrm{SO}_{4}\right)_{2}$ $(0.0085 \mathrm{M})$ in the presence of ferroin indicator. Catalyst productivities are reported as $\mathrm{mol}_{\mathrm{H} 2 \mathrm{O} 2} \mathrm{~kg}_{\mathrm{cat}}{ }^{-1} \mathrm{~h}^{-1}$.

Total autoclave capacity was determined via water displacement to allow for accurate determination of $\mathrm{H}_{2}$ conversion and $\mathrm{H}_{2} \mathrm{O}_{2}$ selectivity. When equipped with a PTFE liner, the total volume of an unfilled autoclave was determined to be $93 \mathrm{~mL}$, which includes all available gaseous space within the autoclave.

Catalytic conversion of $\mathrm{H}_{2}$ and selectivity towards $\mathrm{H}_{2} \mathrm{O}_{2}$ were determined using a Varian $3800 \mathrm{GC}$ fitted with TCD and equipped with a Porapak $\mathrm{Q}$ column.

$\mathrm{H}_{2}$ conversion (Eq. 1) $\mathrm{H}_{2} \mathrm{O}_{2}$ selectivity (Eq. 2) are defined as follows:

$\mathrm{H}_{2}$ Conversion $(\%)=\frac{\mathrm{mmol}_{\mathrm{H} 2(\mathrm{t}(0))}-\mathrm{mmol}_{\mathrm{H} 2(\mathrm{t}(1))}}{\mathrm{mmol}_{\mathrm{H} 2(\mathrm{t}(0))}} \times 100$

$\mathrm{H}_{2} \mathrm{O}_{2}$ Selectivity $(\%)=\frac{\mathrm{H}_{2} \mathrm{O}_{2} \text { detected }(\mathrm{mmol})}{\mathrm{H}_{2} \text { consumed }(\mathrm{mmol})} \times 100$

2.2.2.2 Degradation of $\mathrm{H}_{2} \mathrm{O}_{2}$ Catalytic activity towards $\mathrm{H}_{2} \mathrm{O}_{2}$ degradation (via hydrogenation and decomposition pathways) was determined in a similar manner to that used to measure the direct synthesis activity of a catalyst. The autoclave liner was charged with methanol (5.6 g, HPLC standard, Fischer Scientific), $\mathrm{H}_{2} \mathrm{O}_{2}$ (50 wt. $\%, 0.69$ g, Merck), $\mathrm{H}_{2} \mathrm{O}$ (2.21 g, HPLC standard, Fischer Scientific) and catalyst $(0.01 \mathrm{~g})$, with the solvent composition equivalent to a 4 wt. $\% \mathrm{H}_{2} \mathrm{O}_{2}$ solution. From the solution, prior to the addition of the catalyst, two $0.05 \mathrm{~g}$ aliquots were removed and titrated with acidified $\mathrm{Ce}\left(\mathrm{SO}_{4}\right)_{2}$ solution using ferroin as an indicator to determine an accurate concentration of $\mathrm{H}_{2} \mathrm{O}_{2}$ at the start of the reaction. The autoclave was purged three times with $5 \% \mathrm{H}_{2} / \mathrm{CO}_{2}(100 \mathrm{psi}$ ) before filling with $5 \%$ $\mathrm{H}_{2} / \mathrm{CO}_{2}$ to a gauge pressure of $420 \mathrm{psi}$. The reaction was conducted at a temperature of $2{ }^{\circ} \mathrm{C}$, for $0.5 \mathrm{~h}$ with stirring (1200 rpm). After the reaction was complete the catalyst was removed from the reaction mixture by filtration and two
$0.05 \mathrm{~g}$ aliquots were titrated against the acidified $\mathrm{Ce}\left(\mathrm{SO}_{4}\right)_{2}$ solution using ferroin as an indicator. The degradation activity is reported as $\mathrm{mol}_{\mathrm{H} 2 \mathrm{O} 2} \mathrm{~kg}_{\mathrm{cat}}{ }^{-1} \mathrm{~h}^{-1}$.

\subsubsection{Time-on-Line Analysis for the Direct Synthesis} of $\mathrm{H}_{2} \mathrm{O}_{2}$ An identical procedure to that outlined above for the direct synthesis of $\mathrm{H}_{2} \mathrm{O}_{2}$ is followed for the desired reaction time. It should be noted that individual experiments are carried out and the reaction mixture is not sampled on-line.

\subsubsection{Gas Replacement Experiments for the Direct Syn-} thesis of $\mathrm{H}_{2} \mathrm{O}_{2}$ An identical procedure to that outlined above for the direct synthesis of $\mathrm{H}_{2} \mathrm{O}_{2}$ was followed for a reaction time of $0.5 \mathrm{~h}$. After this, stirring was stopped and the reactant gas mixture was vented prior to replacement with the standard pressures of $5 \% \mathrm{H}_{2} / \mathrm{CO}_{2}(420 \mathrm{psi})$ and $25 \% \mathrm{O}_{2} / \mathrm{CO}_{2}$ $(160 \mathrm{psi})$. The reaction mixture was then stirred $(1200 \mathrm{rpm})$ for a further $0.5 \mathrm{~h}$. To collect a series of data points, as in the case of Fig. 2, it should be noted that individual experiments were carried out and the reactant mixture was not sampled on-line.

2.2.2.5 Catalyst Reusability in the Direct Synthesis and Degradation of $\mathrm{H}_{2} \mathrm{O}_{2}$ In order to determine catalyst reusability a similar procedure to that outlined above for the direct synthesis of $\mathrm{H}_{2} \mathrm{O}_{2}$ is followed utilising $0.05 \mathrm{~g}$ of catalyst. Following the initial test, the catalyst is recovered by filtration and dried $\left(30^{\circ} \mathrm{C}, 16 \mathrm{~h}\right.$, under vacuum), from the recovered catalyst sample $0.01 \mathrm{~g}$ is used to conduct a standard $\mathrm{H}_{2} \mathrm{O}_{2}$ synthesis or degradation experiment.

\subsubsection{The Effect of $\mathrm{Cl}^{-}$as a Promoter in the Direct Synthe-} sis of $\mathrm{H}_{2} \mathrm{O}_{2}$ In order to determine the promotive effect of $\mathrm{Cl}^{-}$ on catalytic activity towards $\mathrm{H}_{2} \mathrm{O}_{2}$ an identical procedure to that outlined above for the direct synthesis of $\mathrm{H}_{2} \mathrm{O}_{2}$ was followed utilising $0.05 \mathrm{~g}$ of catalyst. Following the initial test, the catalyst is recovered by filtration and dried $\left(30^{\circ} \mathrm{C}, 16 \mathrm{~h}\right.$, under vacuum), from the recovered catalyst sample $0.01 \mathrm{~g}$ is used to conduct a standard $\mathrm{H}_{2} \mathrm{O}_{2}$ synthesis, where a proportion of the water co-solvent is replaced with aqueous $\mathrm{Cl}$ in the form of $\mathrm{MgCl}_{2}$ or $\mathrm{CaCl}_{2}$ at concentrations of $\mathrm{Cl}$ comparable to that present in the fresh catalyst.

2.2.2.7 Catalyst Characterisation Brunauer Emmett Teller (BET) surface area measurements were conducted using a Quadrasorb surface area analyser. A 5-point isotherm of each material was measured using $\mathrm{N}_{2}$ as the adsorbate gas. Samples were degassed at $250{ }^{\circ} \mathrm{C}$ for $2 \mathrm{~h}$ prior to the surface area being determined by 5 -point $\mathrm{N}_{2}$ adsorption at $-196^{\circ} \mathrm{C}$, and data analysed using the BET method.

A Thermo Scientific K-Alpha ${ }^{+}$photoelectron spectrometer was used to collect XP spectra utilising a micro-focused monochromatic $\mathrm{Al} \mathrm{K} \mathrm{K}_{\alpha} \mathrm{X}$-ray source operating at $72 \mathrm{~W}$. 
Data was collected over an elliptical area of approximately $400 \mu \mathrm{m}^{2}$ at pass energies of 40 and $150 \mathrm{eV}$ for high-resolution and survey spectra, respectively. Sample charging effects were minimised through a combination of low energy electrons and $\mathrm{Ar}^{+}$ions, consequently this resulted in a $\mathrm{C}(1 \mathrm{~s})$ line at $284.8 \mathrm{eV}$ for all samples. All data was processed using CasaXPS v2.3.24 using a Shirley background, Scofield sensitivity factors [35] and an electron energy dependence of -0.6 as recommended by the manufacturer.

The bulk structure of the catalysts was determined by powder X-ray diffraction using a $(\theta-\theta)$ PANalytical X'pert Pro powder diffractometer using a $\mathrm{Cu} \mathrm{K}_{\alpha}$ radiation source, operating at $40 \mathrm{keV}$ and $40 \mathrm{~mA}$. Standard analysis was carried out using a 40 min run with a back filled sample, between $2 \theta$ values of $10-80^{\circ}$. Phase identification was carried out using the International Centre for Diffraction Data (ICDD).

Transmission electron microscopy (TEM) was performed on a JEOL JEM-2100 operating at $200 \mathrm{kV}$. Samples were prepared by dispersion in ethanol by sonication and deposited on 300 mesh copper grids coated with holey carbon film. Energy dispersive X-ray analysis (EDX) was performed using an Oxford Instruments X-Max ${ }^{\mathrm{N}} 80$ detector and the data analysed using the Aztec software.

Total metal leaching from the supported catalyst was quantified via inductively coupled plasma mass spectrometry (ICP-MS). Post-reaction solutions were analysed using an Agilent 7900 ICP-MS equipped with I-AS auto-sampler. All samples were diluted by a factor of 10 using HPLC grade $\mathrm{H}_{2} \mathrm{O}\left(1 \% \mathrm{HNO}_{3}\right.$ and $0.5 \% \mathrm{HCl}$ matrix $)$. All calibrants were matrix matched and measured against a five-point calibration using certified reference materials purchased from Perkin Elmer and certified internal standards acquired from Agilent.

\section{Results and Discussion}

In keeping with numerous previous works [29, 36], our initial studies established the ability of Au incorporation into a supported $\mathrm{Pd}$ catalyst to significantly improve catalytic performance towards $\mathrm{H}_{2} \mathrm{O}_{2}$ synthesis, with $\mathrm{H}_{2} \mathrm{O}_{2}$ formation rates over the $0.5 \% \mathrm{Au}-0.5 \% \mathrm{Pd} / \mathrm{TiO}_{2}$ catalyst $\left(96 \mathrm{~mol}_{\mathrm{H} 2 \mathrm{O} 2} \mathrm{~kg}_{\mathrm{cat}}{ }^{-1} \mathrm{~h}^{-1}\right.$ ) far greater than that observed over the analogous Au- $\left(1 \mathrm{~mol}_{\mathrm{H} 2 \mathrm{O} 2} \mathrm{~kg}_{\mathrm{cat}}{ }^{-1} \mathrm{~h}^{-1}\right)$ or Pdonly $\left(26 \mathrm{~mol}_{\mathrm{H} 2 \mathrm{O} 2} \mathrm{~kg}_{\mathrm{cat}}{ }^{-1} \mathrm{~h}^{-1}\right)$ materials (Table 1). A corresponding decrease in $\mathrm{H}_{2} \mathrm{O}_{2}$ degradation (via hydrogenation and decomposition) is also observed upon $\mathrm{Au}$ introduction, with the activity of the $1 \% \mathrm{Pd} / \mathrm{TiO}_{2}$ catalyst $\left(269 \mathrm{~mol}_{\mathrm{H} 2 \mathrm{O} 2} \mathrm{~kg}_{\mathrm{cat}}{ }^{-1} \mathrm{~h}^{-1}\right)$ somewhat greater than that of the $0.5 \% \mathrm{Au}-0.5 \% \mathrm{Pd} / \mathrm{TiO}_{2}$ catalyst $\left(227 \mathrm{~mol}_{\mathrm{H} 2 \mathrm{O} 2} \mathrm{~kg}_{\mathrm{cat}}{ }^{-1} \mathrm{~h}^{-1}\right)$.

Analysis of the $1 \% \mathrm{AuPd} / \mathrm{TiO}_{2}$ catalysts, reported in Table 1, by X-ray diffraction (Figure S.1) reveals no reflections associated with either Au or Pd, likely resulting from
Table 1 Catalytic activity towards the direct synthesis and subsequent degradation of $\mathrm{H}_{2} \mathrm{O}_{2}$

\begin{tabular}{lll}
\hline Catalyst & $\begin{array}{l}\text { Productivity/ } \\
\mathrm{mol}_{\mathrm{H} 2 \mathrm{O} 2} \mathrm{~kg}_{\mathrm{cat}} \\
\left(\mathrm{H}_{2} \mathrm{O}_{2} \mathrm{wt} . \%\right)\end{array}$ & $\begin{array}{l}\text { Degradation/ } \\
\mathrm{mol}_{\mathrm{H} 222} \mathrm{~kg}_{\mathrm{cat}}{ }^{-1} \mathrm{~h}^{-1}\end{array}$ \\
\hline $1 \% \mathrm{Au} / \mathrm{TiO}_{2}$ & $1(0.003)$ & 9 \\
$0.75 \% \mathrm{Au}-0.25 \% \mathrm{Pd} /$ & $32(0.070)$ & 70 \\
$\mathrm{TiO}_{2}$ & & 227 \\
$0.5 \% \mathrm{Au}-0.5 \% \mathrm{Pd} / \mathrm{TiO}_{2}$ & $96(0.190)$ & 247 \\
$0.25 \% \mathrm{Au}-0.75 \% \mathrm{Pd} /$ & $87(0.180)$ & \\
$\mathrm{TiO} \mathrm{F}_{2}$ & $26(0.050)$ & 269 \\
$1 \% \mathrm{Pd} / \mathrm{TiO}_{2}$ &
\end{tabular}

$\mathrm{H}_{2} \mathrm{O}_{2}$ direct synthesis reaction conditions: Catalyst $(0.01 \mathrm{~g}), \mathrm{H}_{2} \mathrm{O}$ (2.9 g), $\mathrm{MeOH}(5.6 \mathrm{~g}), 5 \% \mathrm{H}_{2} / \mathrm{CO}_{2}$ (420 psi), 25\% $\mathrm{O}_{2} / \mathrm{CO}_{2}$ (160 psi), $0.5 \mathrm{~h}, 2{ }^{\circ} \mathrm{C} 1200 \mathrm{rpm} . \mathrm{H}_{2} \mathrm{O}_{2}$ degradation reaction conditions: Catalyst $(0.01 \mathrm{~g}), \mathrm{H}_{2} \mathrm{O}_{2}(50$ wt. $\% 0.68 \mathrm{~g}) \mathrm{H}_{2} \mathrm{O}(2.22 \mathrm{~g}), \mathrm{MeOH}(5.6 \mathrm{~g}), 5 \% \mathrm{H}_{2} /$ $\mathrm{CO}_{2}(420 \mathrm{psi}), 0.5 \mathrm{~h}, 2{ }^{\circ} \mathrm{C} 1200 \mathrm{rpm}$

Table 2 Mean particle size of $1 \% \mathrm{AuPd} / \mathrm{TiO}_{2}$ catalysts, prepared via an excess chloride impregnation methodology, as determined by transmission electron microscopy

\begin{tabular}{ll}
\hline Catalyst & $\begin{array}{l}\text { Mean particle size/ } \\
\text { nm (Standard devia- } \\
\text { tion) }\end{array}$ \\
\hline $1 \% \mathrm{Au} / \mathrm{TiO}_{2}$ & $24.9(7.9)$ \\
$0.75 \% \mathrm{Au}-0.25 \% \mathrm{Pd} / \mathrm{TiO}_{2}$ & $13.1(8.3)$ \\
$0.5 \% \mathrm{Au}-0.5 \% \mathrm{Pd} / \mathrm{TiO}_{2}$ & $4.2(1.8)$ \\
$0.25 \% \mathrm{Au}-0.75 \% \mathrm{Pd} / \mathrm{TiO}_{2}$ & $6.5(8.5)$ \\
$1 \% \mathrm{Pd} / \mathrm{TiO}_{2}$ & n.d \\
\hline
\end{tabular}

*Unable to determine due to particle sizes being below TEM limits of detection

the low total metal loading of these materials. While measurement of the mean nanoparticle size (Table 2) as determined by bright field transmission electron microscopy (BFTEM) (representative micrographs can be seen in Figure S.2) indicates that upon the alloying of $\mathrm{Au}$ and $\mathrm{Pd}$, mean particle size decreases dramatically compared to the $1 \% \mathrm{Au} /$ $\mathrm{TiO}_{2}$ catalyst $(24.9 \mathrm{~nm})$, with the $0.5 \% \mathrm{Au}-0.5 \% \mathrm{Pd} / \mathrm{TiO}_{2}$ catalyst displaying a mean particle size of $4.2 \mathrm{~nm}$. Although it is interesting to note that the mean particle size of the $0.25 \% \mathrm{Au}-0.75 \% \mathrm{Pd} / \mathrm{TiO}_{2}$ catalyst is somewhat larger than that of both the $0.5 \% \mathrm{Au}-0.5 \% \mathrm{Pd} / \mathrm{TiO}_{2}$ and $1 \% \mathrm{Pd} / \mathrm{TiO}_{2}$ analogues, indicating that $\mathrm{Au}: \mathrm{Pd}$ ratio can have a significant effect on metal dispersion. Further analysis via X-ray photoelectron spectroscopy (XPS) (Figure S.3) reveals that the introduction of Au into a monometallic Pd catalyst significantly modifies Pd-oxidation state, with an increase in $\mathrm{Pd}^{2+}$ content observed. The presence of domains of mixed $\mathrm{Pd}$ oxidation state has been well reported to improve catalytic performance towards $\mathrm{H}_{2} \mathrm{O}_{2}$ synthesis compared to $\mathrm{Pd}^{2+}$ or $\mathrm{Pd}^{0}$-rich analogues [37-39]. As such, we consider that 
this combination of relatively small nanoparticles, of mixed Pd-oxidation state may be a key factor responsible for the enhanced activity observed over the $0.5 \% \mathrm{Au}-0.5 \% \mathrm{Pd} / \mathrm{TiO}_{2}$ catalyst.

For numerous applications, the continual in-situ production of low concentrations of stabiliser free $\mathrm{H}_{2} \mathrm{O}_{2}$ would be preferred, compared to the addition of aqueous solutions of $\mathrm{H}_{2} \mathrm{O}_{2}$ [32]. With this in mind and building on our initial studies, we subsequently established the activity of a series of supported AuPd catalysts, of various total metal loading, toward the direct synthesis of $\mathrm{H}_{2} \mathrm{O}_{2}$ (Table 3). A direct relationship between total nominal metal loading and catalytic activity towards both $\mathrm{H}_{2} \mathrm{O}_{2}$ synthesis and its subsequent degradation is apparent, with the $0.5 \% \mathrm{Au}-0.5 \% \mathrm{Pd} /$ $\mathrm{TiO}_{2}$ catalyst offering the greatest activity towards both reaction pathways. Interestingly the $0.0625 \% \mathrm{Au}-0.0625 \% \mathrm{Pd} /$ $\mathrm{TiO}_{2}$ catalyst offers exceptionally low activity towards $\mathrm{H}_{2} \mathrm{O}_{2}$ synthesis, possibly lower than would be expected given the strong correlation between metal content and catalytic performance observed across the catalyst series. In keeping with the observed correlation between total metal loading and $\mathrm{H}_{2} \mathrm{O}_{2}$ degradation, catalytic selectivity towards $\mathrm{H}_{2}$ (i.e. the amount of $\mathrm{H}_{2}$ utilised in the production of $\mathrm{H}_{2} \mathrm{O}_{2}$ ) is also seen to correlate well with metal content, with the $0.125 \%$ $\mathrm{Au}-0.125 \% \mathrm{Pd} / \mathrm{TiO}_{2}$ catalyst displaying higher selectivity towards $\mathrm{H}_{2}(71 \%)$, that higher metal loading analogues.

With the observed variation in catalytic performance under our standard reaction conditions, we were motivated to further investigate this series of supported AuPd catalysts. Time-on-line studies comparing catalytic performance towards $\mathrm{H}_{2} \mathrm{O}_{2}$ production over the supported AuPd catalysts can be seen in Fig. 1 with the enhanced activity of the $0.5 \%$ $\mathrm{Au}-0.5 \% \mathrm{Pd} / \mathrm{TiO}_{2}$ catalyst clear over the course of a $1 \mathrm{~h}$ reaction, with concentrations of $\mathrm{H}_{2} \mathrm{O}_{2}(0.30$ wt. \%) near double that produced over the $0.25 \% \mathrm{Au}-0.25 \% \mathrm{Pd} / \mathrm{TiO}_{2}$ catalyst, $(0.17 \mathrm{wt} . \%)$ which in turn is near double that produced over the $0.125 \% \mathrm{Au}-0.125 \% \mathrm{Pd} / \mathrm{TiO}_{2}$ analogue $(0.08$ wt. $\%)$. The enhanced activity of the $0.5 \% \mathrm{Au}-0.5 \% \mathrm{Pd} / \mathrm{TiO}_{2}$ catalyst

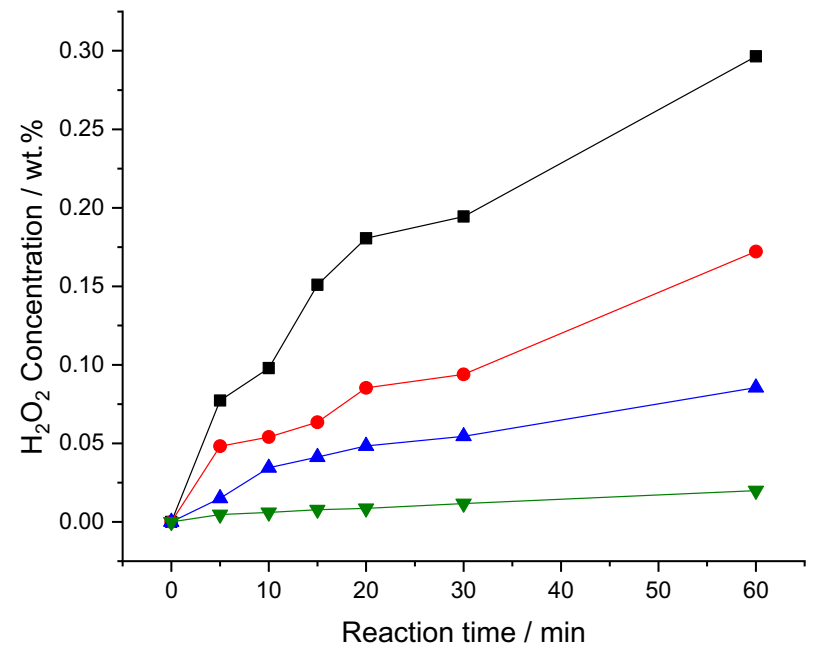

Fig. 1 Comparison of catalytic activity towards $\mathrm{H}_{2} \mathrm{O}_{2}$ synthesis as a function of reaction time. $\mathrm{H}_{2} \mathrm{O}_{2}$ direct synthesis reaction conditions: Catalyst (0.01 g), $\mathrm{H}_{2} \mathrm{O}(2.9 \mathrm{~g}), \mathrm{MeOH}(5.6 \mathrm{~g}), 5 \% \mathrm{H}_{2} / \mathrm{CO}_{2}$ (420 psi), 25\% $\mathrm{O}_{2} / \mathrm{CO}_{2}$ (160 psi), $0.5 \mathrm{~h}, 2{ }^{\circ} \mathrm{C} 1200 \mathrm{rpm}$. Key: $0.5 \%$ $\mathrm{Au}-0.5 \% \mathrm{Pd} / \mathrm{TiO}_{2}$ (Black squares), $0.25 \% \mathrm{Au}-0.25 \% \mathrm{Pd} / \mathrm{TiO}{ }_{2}$ (Red circles), $0.125 \% \mathrm{Au}-0.125 \% \mathrm{Pd} / \mathrm{TiO}_{2}$ (Blue triangles), $0.0625 \% \mathrm{Au}-$ $0.0625 \% \mathrm{Pd} / \mathrm{TiO}_{2}$ (Green inverted triangles)

is also highlighted through comparison of calculated reaction rates at reaction times where there is assumed to be no contribution from subsequent degradation reactions or limitations associated with reactant availability (Table S.2).

Evaluation of catalytic activity over multiple sequential $\mathrm{H}_{2} \mathrm{O}_{2}$ synthesis tests, where the reactant gas is replaced at $0.5 \mathrm{~h}$ intervals, can be seen in Fig. 2. In keeping with our previous observations, a marked enhancement in $\mathrm{H}_{2} \mathrm{O}_{2}$ concentration is observed for the $0.5 \% \mathrm{Au}-0.5 \% \mathrm{Pd} / \mathrm{TiO}_{2}$ catalyst compared to the remaining AuPd catalysts, with this value increasing to a value of $0.61 \mathrm{wt} . \%$ after five consecutive synthesis reactions. It should be noted that concentrations of $\mathrm{H}_{2} \mathrm{O}_{2}$ achieved by the $0.5 \% \mathrm{Au}-0.5 \% \mathrm{Pd} / \mathrm{TiO}_{2}$ catalyst is comparable to that achieved during the initial stages

Table 3 Summary of catalytic testing data for supported $\mathrm{AuPd} / \mathrm{TiO}_{2}$ catalysts as a function of total metal loading

\begin{tabular}{lllllll}
\hline Catalyst & $\begin{array}{l}\text { Productivity/ } \\
\mathrm{mol}_{\mathrm{H} 2 \mathrm{O} 2} \mathrm{~kg}_{\mathrm{cat}}{ }^{-1} \mathrm{~h}^{-1}\end{array}$ & $\mathrm{H}_{2} \mathrm{O}_{2} / \mathrm{wt} \%$ & $\mathrm{H}_{2}$ Con./\% & $\mathrm{H}_{2} \mathrm{O}_{2}$ Sel./\% & $\begin{array}{l}\text { Apparent reaction rate at } \\
0.5 \mathrm{~h}^{-1} \mathrm{mmol}_{\mathrm{H} 22} \mathrm{mmol}^{-} \\
\mathrm{metal}^{-1} \mathrm{~h}^{-1}\end{array}$ & $\begin{array}{l}\text { Degradation/ } \\
\mathrm{mol}_{\mathrm{H} 2 \mathrm{O} 2} \mathrm{~kg}_{\mathrm{cat}}{ }^{-1} \mathrm{~h}^{-1}\end{array}$ \\
\hline $0.5 \% \mathrm{Au}-0.5 \% \mathrm{Pd} / \mathrm{TiO}_{2}$ & 96 & 0.19 & 24.4 & 53.1 & $1.24 \times 10^{3}$ & 227 \\
$0.25 \% \mathrm{Au}-0.25 \% \mathrm{Pd} / \mathrm{TiO}_{2}$ & 56 & 0.11 & 12.4 & 64.8 & $1.54 \times 10^{3}$ & 156 \\
$0.125 \% \mathrm{Au}-0.125 \% \mathrm{Pd} / \mathrm{TiO}_{2}$ & 29 & 0.05 & 8.1 & 71.0 & $2.19 \times 10^{3}$ & 88 \\
$0.0625 \% \mathrm{Au}-0.0625 \% \mathrm{Pd} / \mathrm{TiO}_{2}$ & 5 & 0.01 & $\mathrm{~N} . \mathrm{D}$ & $\mathrm{N} . \mathrm{D}$ & $3.82 \times 10^{2}$ & 72 \\
$\mathrm{TiO}_{2}$ & 0 & 0 & 0 & 0 & 0 & 0 \\
\hline
\end{tabular}

$\mathrm{H}_{2} \mathrm{O}_{2}$ direct synthesis reaction conditions: Catalyst $(0.01 \mathrm{~g}), \mathrm{H}_{2} \mathrm{O}(2.9 \mathrm{~g}), \mathrm{MeOH}(5.6 \mathrm{~g}), 5 \% \mathrm{H}_{2} / \mathrm{CO}_{2}(420 \mathrm{psi}), 25 \% \mathrm{O}_{2} / \mathrm{CO}_{2}(160 \mathrm{psi}), 0.5 \mathrm{~h}$,

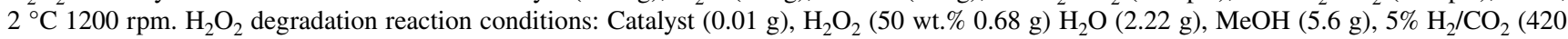
psi), $0.5 \mathrm{~h}, 2{ }^{\circ} \mathrm{C} 1200 \mathrm{rpm}$

N.D unable to determine due to detection limits 


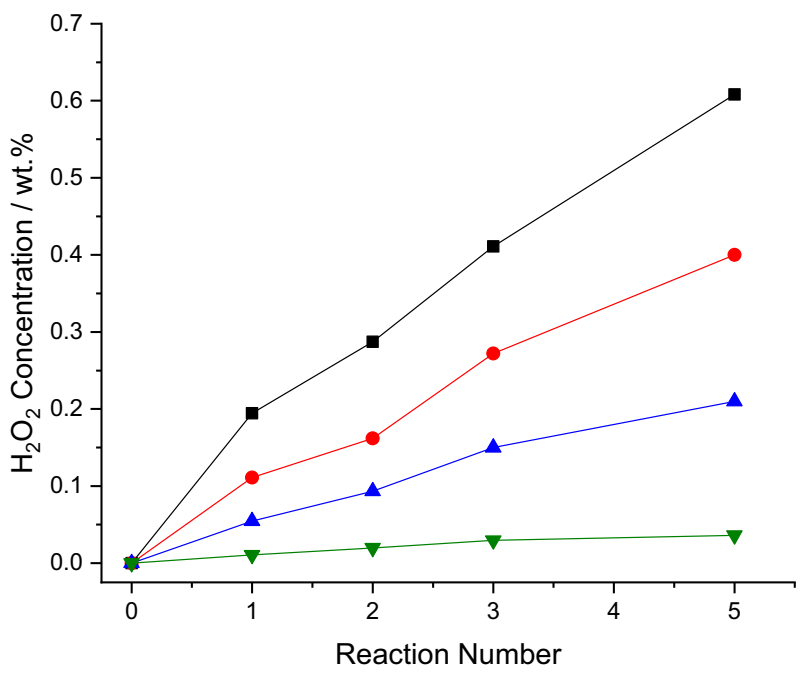

Fig. 2 Comparison of catalytic activity over sequential $\mathrm{H}_{2} \mathrm{O}_{2}$ synthesis reactions. $\mathrm{H}_{2} \mathrm{O}_{2}$ direct synthesis reaction conditions: Catalyst (0.01 g), $\mathrm{H}_{2} \mathrm{O}(2.9 \mathrm{~g}), \mathrm{MeOH}(5.6 \mathrm{~g}), 5 \% \mathrm{H}_{2} / \mathrm{CO}_{2}(420 \mathrm{psi}), 25 \% \mathrm{O}_{2} /$ $\mathrm{CO}_{2}$ (160 psi), $0.5 \mathrm{~h}, 2{ }^{\circ} \mathrm{C} 1200 \mathrm{rpm}$. Key: $0.5 \% \mathrm{Au}-0.5 \% \mathrm{Pd} / \mathrm{TiO}_{2}$ (Black squares), $0.25 \% \mathrm{Au}-0.25 \% \mathrm{Pd} / \mathrm{TiO}_{2}$ (Red circles), $0.125 \% \mathrm{Au}-$ $0.125 \% \mathrm{Pd} / \mathrm{TiO}_{2}$ (Blue triangles), $0.0625 \% \mathrm{Au}-0.0625 \% \quad \mathrm{Pd} / \mathrm{TiO}_{2}$ (Green inverted triangles)

of the industrial route to $\mathrm{H}_{2} \mathrm{O}_{2}$ production, prior to the use of multiple distillation steps to raise $\mathrm{H}_{2} \mathrm{O}_{2}$ concentrations to exceed 70 wt.\% [40].

With the requirement to reuse a catalyst successfully at the heart of green chemistry and the activity of homogeneous species towards $\mathrm{H}_{2} \mathrm{O}_{2}$ formation well known [41], we next evaluated catalytic activity towards $\mathrm{H}_{2} \mathrm{O}_{2}$ synthesis and $\mathrm{H}_{2} \mathrm{O}_{2}$ degradation pathways upon reuse (Table 4). It can be seen that for all catalysts, $\mathrm{H}_{2} \mathrm{O}_{2}$ synthesis rates decreased significantly, with a corresponding decrease in

Table 4 Catalyst reusability towards the direct synthesis and subsequent degradation of $\mathrm{H}_{2} \mathrm{O}_{2}$

\begin{tabular}{|c|c|c|c|c|}
\hline \multirow[t]{2}{*}{ Catalyst } & \multicolumn{2}{|c|}{$\begin{array}{l}\text { Productivity/ } \\
\text { mol }_{\mathrm{H} 2 \mathrm{O} 2} \mathrm{~kg}_{\text {cat }}{ }^{-1} \mathrm{~h}^{-1}\end{array}$} & \multicolumn{2}{|c|}{$\begin{array}{l}\text { Degradation/ } \\
\text { mol }_{\mathrm{H} 2 \mathrm{O} 2} \mathrm{~kg}_{\text {cat }}{ }^{-1} \mathrm{~h}^{-1}\end{array}$} \\
\hline & $1^{\text {st }}$ use & $\begin{array}{l}2^{\text {nd }} \\
\text { use }\end{array}$ & $1^{\text {st }}$ use & $2^{\text {nd }}$ use \\
\hline $0.5 \% \mathrm{Au}-0.5 \% \mathrm{Pd} / \mathrm{TiO}_{2}$ & 96 & 38 & 227 & 249 \\
\hline $\begin{array}{l}0.25 \% \mathrm{Au}-0.25 \% \mathrm{Pd} / \\
\mathrm{TiO}_{2}\end{array}$ & 56 & 18 & 156 & 150 \\
\hline $\begin{array}{l}0.125 \% \mathrm{Au}-0.125 \% \mathrm{Pd} / \\
\mathrm{TiO}_{2}\end{array}$ & 29 & 11 & 88 & 54 \\
\hline $\begin{array}{l}0.0625 \% \mathrm{Au}-0.0625 \% \mathrm{Pd} / \\
\mathrm{Ti} \mathrm{O}_{2}\end{array}$ & 5 & 4 & 72 & 5 \\
\hline
\end{tabular}

$\mathrm{H}_{2} \mathrm{O}_{2}$ direct synthesis reaction conditions: Catalyst $(0.01 \mathrm{~g}), \mathrm{H}_{2} \mathrm{O}$ (2.9 g), $\mathrm{MeOH}$ (5.6 g), $5 \% \mathrm{H}_{2} / \mathrm{CO}_{2}$ (420 psi), $25 \% \mathrm{O}_{2} / \mathrm{CO}_{2}$ (160 psi), $0.5 \mathrm{~h}, 2{ }^{\circ} \mathrm{C} 1200 \mathrm{rpm} . \mathrm{H}_{2} \mathrm{O}_{2}$ degradation reaction conditions: Catalyst (0.01 g), $\mathrm{H}_{2} \mathrm{O}_{2}$ (50 wt. \% 0.68 g) $\mathrm{H}_{2} \mathrm{O}(2.22 \mathrm{~g}), \mathrm{MeOH}(5.6 \mathrm{~g}), 5 \% \mathrm{H}_{2} /$ $\mathrm{CO}_{2}(420 \mathrm{psi}), 0.5 \mathrm{~h}, 2{ }^{\circ} \mathrm{C} 1200 \mathrm{rpm}$ initial reaction rate (Table S.2). This loss of catalytic performance upon reuse cannot be ascribed to leaching of metal species, as evidenced from analysis of the $\mathrm{H}_{2} \mathrm{O}_{2}$ synthesis reaction solution by ICP-MS (Table S.3), which reveals the high stability of the AuPd catalysts during the $\mathrm{H}_{2} \mathrm{O}_{2}$ synthesis reaction. XPS analysis of the catalysts, as-prepared and after use in the direct synthesis reaction indicates a minor increase in the proportion of $\mathrm{Pd}^{0}$ as a result of use in the direct synthesis reaction, (Figure S.4), likely as a result of in-situ reduction. While the high activity of $\mathrm{Pd}^{0}$-rich species towards the degradation of $\mathrm{H}_{2} \mathrm{O}_{2}$ is well known [42] we cannot ascribe the loss of $\mathrm{H}_{2} \mathrm{O}_{2}$ synthesis activity observed upon reuse to an increase in competitive $\mathrm{H}_{2} \mathrm{O}_{2}$ degradation reactions, with this metric comparable in both the initial and second use of these materials in the degradation reaction (Table 4). However, our analysis via XPS does reveal a significant loss in chloride content after use in the direct synthesis reaction, (Figure S.5) with halide ions well known promoters for the direct synthesis reaction it is likely that the loss of $\mathrm{Cl}$ is responsible for the observed decrease in catalytic activity towards $\mathrm{H}_{2} \mathrm{O}_{2}$ formation. Indeed, subsequent studies, where $\mathrm{Cl}$ (in the form of $\mathrm{CaCl}_{2}$ or $\mathrm{MgCl}_{2}$ ) is used in conjunction with a used $0.5 \% \mathrm{Au}-0.5 \% \mathrm{Pd} / \mathrm{TiO}_{2}$ catalyst leads to a dramatic improvement in $\mathrm{H}_{2} \mathrm{O}_{2}$ synthesis activity, further highlighting the promotional role of $\mathrm{Cl}$ (Figure S.6).

With the observed loss in $\mathrm{H}_{2} \mathrm{O}_{2}$ synthesis activity upon reuse we were motivated to investigate the effect of heat treatment regime on catalyst reusability, with a focus on the $0.5 \% \mathrm{Au}-0.5 \% \mathrm{Pd} / \mathrm{TiO}_{2}$ catalyst (Table 5). We have previously demonstrated that AuPd catalysts prepared via

Table 5 Reusability of the $0.5 \% \mathrm{Au}-0.5 \% \mathrm{Pd} / \mathrm{TiO}_{2}$ catalyst towards the direct synthesis and subsequent degradation of $\mathrm{H}_{2} \mathrm{O}_{2}$, as a function of heat treatment regime

\begin{tabular}{|c|c|c|c|c|}
\hline \multirow[t]{2}{*}{ Heat treatment } & \multicolumn{2}{|c|}{$\begin{array}{l}\text { Productivity/ } \\
\text { mol }_{\mathrm{H} 2 \mathrm{O} 2} \mathrm{~kg}_{\text {cat }}{ }^{-1} \mathrm{~h}^{-1}\end{array}$} & \multicolumn{2}{|c|}{$\begin{array}{l}\text { Degradation/ } \\
\text { mol }_{\mathrm{H} 2 \mathrm{O} 2} \mathrm{~kg}_{\text {cat }}{ }^{-1} \mathrm{~h}^{-1}\end{array}$} \\
\hline & $1^{\text {st }}$ use & $2^{\text {nd }}$ use & $1^{\text {st }}$ use & $2^{\text {nd }}$ use \\
\hline $\begin{array}{l}\text { Reduction }\left(4 \mathrm{~h} 400{ }^{\circ} \mathrm{C} \text {, }\right. \\
\left.5 \% \mathrm{H}_{2} / \mathrm{Ar}\right)\end{array}$ & 96 & 38 & 227 & 249 \\
\hline $\begin{array}{l}\text { Calcination }\left(4 \mathrm{~h} 400^{\circ} \mathrm{C} \text {, }\right. \\
\text { air) }\end{array}$ & 71 & 40 & 123 & 200 \\
\hline $\begin{array}{l}\text { Calcination }\left(4 \mathrm{~h} 400{ }^{\circ} \mathrm{C} \text {, }\right. \\
\text { air })+ \text { Reduction }(2 \mathrm{~h} \\
\left.200{ }^{\circ} \mathrm{C}, 5 \% \mathrm{H}_{2} / \mathrm{Ar}\right)\end{array}$ & 64 & 42 & 84 & 173 \\
\hline $\begin{array}{l}\text { Calcination }\left(4 \mathrm{~h} 400{ }^{\circ} \mathrm{C} \text {, }\right. \\
\text { air }+ \text { Reduction }(2 \mathrm{~h} \\
\left.200{ }^{\circ} \mathrm{C}, 5 \% \mathrm{H}_{2} / \mathrm{Ar}\right)\end{array}$ & 67 & 47 & 100 & 221 \\
\hline
\end{tabular}

$\mathrm{H}_{2} \mathrm{O}_{2}$ direct synthesis reaction conditions: Catalyst $(0.01 \mathrm{~g}), \mathrm{H}_{2} \mathrm{O}$ (2.9 g), $\mathrm{MeOH}$ (5.6 g), 5\% $\mathrm{H}_{2} / \mathrm{CO}_{2}$ (420 psi), $25 \% \mathrm{O}_{2} / \mathrm{CO}_{2}$ (160 psi), $0.5 \mathrm{~h}, 2{ }^{\circ} \mathrm{C} 1200 \mathrm{rpm} . \mathrm{H}_{2} \mathrm{O}_{2}$ degradation reaction conditions: Catalyst (0.01 g), $\mathrm{H}_{2} \mathrm{O}_{2}(50$ wt. $\% 0.68 \mathrm{~g}) \mathrm{H}_{2} \mathrm{O}(2.22 \mathrm{~g}), \mathrm{MeOH}(5.6 \mathrm{~g}), 5 \% \mathrm{H}_{2} /$ $\mathrm{CO}_{2}(420 \mathrm{psi}), 0.5 \mathrm{~h}, 2{ }^{\circ} \mathrm{C} 1200 \mathrm{rpm}$ 
a conventional wet co-impregnation procedure and exposed to an oxidative heat treatment are stable over multiple uses [43]. With this in mind the as-prepared $0.5 \% \mathrm{Au}-0.5 \% \mathrm{Pd} /$ $\mathrm{TiO}_{2}$ catalyst was first subjected to calcination $\left(4 \mathrm{~h}, 400{ }^{\circ} \mathrm{C}\right.$, flowing air) followed by a reductive heat treatment $(2 \mathrm{~h}$, $200-400{ }^{\circ} \mathrm{C}, 5 \% \mathrm{H}_{2} / \mathrm{Ar}$ ).

It can be seen that exposure of the $0.5 \% \mathrm{Au}-0.5 \% \mathrm{Pd} /$ $\mathrm{TiO}_{2}$ catalyst to calcination only or calcination followed by reduction results in a decreased activity toward both the direct synthesis of $\mathrm{H}_{2} \mathrm{O}_{2}$ and its subsequent degradation in comparison to the reduced only analogue. However, in a similar manner to the $0.5 \% \mathrm{Au}-0.5 \% \mathrm{Pd} / \mathrm{TiO}_{2}$ catalyst exposed to a reductive heat treatment only, all catalysts show a loss in $\mathrm{H}_{2} \mathrm{O}_{2}$ synthesis activity upon reuse. Interestingly the $\mathrm{H}_{2} \mathrm{O}_{2}$ degradation rates of the catalysts exposed to a calcination, either as a single heat treatment or as part of a two-stage process increase significantly upon reuse, while the rise in $\mathrm{H}_{2} \mathrm{O}_{2}$ degradation of the reduced only sample is comparatively negligible.

Analysis of post reaction solutions via ICP-MS reveals that, unlike in the case of the $0.5 \% \mathrm{Au}-0.5 \% \mathrm{Pd} / \mathrm{TiO}_{2}$ catalyst exposed to a reductive heat treatment $\left(4 \mathrm{~h}, 400^{\circ} \mathrm{C}, 5 \%\right.$ $\mathrm{H}_{2} / \mathrm{Ar}$ ) alone, exposure to either calcination alone or calcination followed by low temperature reduction $\left(2 \mathrm{~h}, 200^{\circ} \mathrm{C}\right.$, $5 \% \mathrm{H}_{2} / \mathrm{Ar}$ ) does result in a small amount of precious metal leaching, indicating the clear benefit of high temperature reduction on catalyst stability (Table S.4). While the loss of precious metal species, in addition to the decrease in catalytic selectivity, as indicated by increased rates of $\mathrm{H}_{2} \mathrm{O}_{2}$ degradation, could be responsible for the observed decrease in catalyst performance for the samples exposed to calcination or calcination followed by low temperature reduction, the stability of the sample exposed to high temperature reduction alone indicates an alternative route to deactivation.

Further analysis of the catalysts exposed to a range of heat treatment regimens via XPS (Figure S.7) establishes that $\mathrm{Pd}$ exists as both $\mathrm{Pd}^{0}$ and $\mathrm{Pd}^{2+}$, regardless of heat treatment regime, perhaps unsurprisingly with the exception of the calcined only sample, where Pd exists entirely as $\mathrm{Pd}^{2+}$. In all cases a mixed Pd oxidation state is observed upon reuse, with a slightly increased proportion of $\mathrm{Pd}^{0}$ observed in those samples which displayed mixed states in the as-prepared materials. As previously observed for the $0.5 \% \mathrm{Au}-0.5 \%$ $\mathrm{Pd} / \mathrm{TiO}_{2}$ catalyst exposed to a reductive heat treatment alone, there is a significant loss of surface $\mathrm{Cl}$ content upon use in the direct synthesis reaction for all catalysts (Figure S.8) and it is this which we consider to be the fundamental cause for the loss in catalytic performance observed upon reuse.

\section{Conclusion}

The ability of $\mathrm{Au}$ incorporation to improve catalytic activity towards the direct synthesis of $\mathrm{H}_{2} \mathrm{O}_{2}$ is demonstrated, with the synergistic effects observed when Au and Pd are combined in a 1:1 ratio (wt./wt.) attributed to the development of Pd domains of mixed oxidation state and increased control of nanoparticle size, compared to $\mathrm{Au}$ - or Pd-rich analogues. Building on these findings we subsequently established a direct correlation between the total metal loading of supported AuPd catalysts with catalytic activity towards both $\mathrm{H}_{2} \mathrm{O}_{2}$ synthesis and its subsequent degradation. Catalytic activity towards $\mathrm{H}_{2} \mathrm{O}_{2}$ synthesis is observed to decrease significantly upon reuse, with this loss in catalytic performance ascribed to the loss of $\mathrm{Cl}$, a known promoter for catalytic activity towards $\mathrm{H}_{2} \mathrm{O}_{2}$ production.

Supplementary Information The online version contains supplementary material available at https://doi.org/10.1007/s10562-021-03632-6.

Acknowledgements The authors wish to thank the Cardiff University electron microscope facility for the transmission electron microscopy. XPS data collection was performed at the EPSRC National Facility for XPS ('HarwellXPS'), operated by Cardiff University and UCL, under contract No. PR16195.

\section{Declarations}

Conflict of interest There are no conflicts to declare.

Open Access This article is licensed under a Creative Commons Attribution 4.0 International License, which permits use, sharing, adaptation, distribution and reproduction in any medium or format, as long as you give appropriate credit to the original author(s) and the source, provide a link to the Creative Commons licence, and indicate if changes were made. The images or other third party material in this article are included in the article's Creative Commons licence, unless indicated otherwise in a credit line to the material. If material is not included in the article's Creative Commons licence and your intended use is not permitted by statutory regulation or exceeds the permitted use, you will need to obtain permission directly from the copyright holder. To view a copy of this licence, visit http://creativecommons.org/licenses/by/4.0/.

\section{References}

1. Lewis RJ, Hutchings GJ (2019) Recent advances in the direct synthesis of $\mathrm{H}_{2} \mathrm{O}_{2}$. ChemCatChem 11:298-308

2. Campos-Martin JM, Blanco-Brieva G, Fierro JL (2006) Hydrogen peroxide synthesis: an outlook beyond the anthraquinone process. Angew Chem Int Ed 45:6962-6984

3. Edwards JK, Freakley SJ, Lewis RJ, Pritchard JC, Hutchings GJ (2015) Advances in the direct synthesis of hydrogen peroxide from hydrogen and oxygen. Catal Today 248:3-9

4. Wegner $P$ (2003) Hydrogen peroxide stabilizer and resulting product and applications US20050065052A15

5. Edwards JK, Solsona B, Landon P, Carley AF, Herzing A, Watanabe M, Kiely CJ, Hutchings GJ (2005) Direct synthesis of 
hydrogen peroxide from $\mathrm{H}_{2}$ and $\mathrm{O}_{2}$ using $\mathrm{Au}-\mathrm{Pd} / \mathrm{Fe}_{2} \mathrm{O}_{3}$ catalysts. J Mater Chem 15:4595-4600

6. Blaser B, Worms K, Schiefer J (1964) Stabilizing agent for peroxy-compunds and their solutions US3122417A

7. Lewis RJ, Edwards JK, Freakley SJ, Hutchings GJ (2017) Solid acid additives as recoverable promoters for the direct synthesis of hydrogen peroxide. Ind Eng Chem Res 56:13287-13293

8. Seo M, Kim HJ, Han SS, Lee KY (2017) Direct synthesis of hydrogen peroxide from hydrogen and oxygen using tailored Pd nanocatalysts: a review of recent findings. Catal Surv Asia 21:1-12

9. Flaherty DW (2018) Direct synthesis of $\mathrm{H}_{2} \mathrm{O}_{2}$ from $\mathrm{H}_{2}$ and $\mathrm{O}_{2}$ on Pd catalysts: current understanding, outstanding questions, and research needs. ACS Catal 8:1520-1527

10. Tian P, Ouyang L, Xu X, Ao C, Xu X, Si R, Shen X, Lin M, Xu J, Han Y (2017) The origin of palladium particle size effects in the direct synthesis of $\mathrm{H}_{2} \mathrm{O}_{2}$ : is smaller better? J Catal 349:30-40

11. Kim S, Lee D, Lee K, Cho E (2014) Effect of Pd particle size on the direct synthesis of hydrogen peroxide from hydrogen and oxygen over Pd core-porous $\mathrm{SiO}_{2}$ shell catalysts. Catal Lett 144:905-911

12. Arrigo R, Schuster ME, Abate S, Wrabetz S, Amakawa K, Teschner D, Freni M, Centi G, Perathoner S, Hävecker M, Schlögl R (2014) Dynamics of palladium on nanocarbon in the direct synthesis of $\mathrm{H}_{2} \mathrm{O}_{2}$. Chemsuschem 7:179-194

13. Wilson NM, Flaherty DW (2016) Mechanism for the direct synthesis of $\mathrm{H}_{2} \mathrm{O}_{2}$ on Pd clusters: heterolytic reaction pathways at the liquid-solid interface. J Am Chem Soc 138:574-586

14. Adams JS, Chemburkar A, Priyadarshini P, Ricciardulli T, Lu Y, Maliekkal V, Sampath A, Winikoff S, Karim AM, Neurock M, Flaherty DW (2021) Solvent molecules form surface redox mediators in situ and cocatalyze $\mathrm{O}_{2}$ reduction on Pd. Science 371:626-632

15. Freakley SJ, He Q, Harrhy JH, Lu L, Crole DA, Morgan DJ, Ntainjua EN, Edwards JK, Carley AF, Borisevich AY, Kiely CJ, Hutchings GJ (2016) Palladium-tin catalysts for the direct synthesis of $\mathrm{H}_{2} \mathrm{O}_{2}$ with high selectivity. Science 351:965-968

16. Crole DA, Underhill R, Edwards JK, Shaw G, Freakley SJ, Hutchings GJ, Lewis RJ (2020) The direct synthesis of hydrogen peroxide from $\mathrm{H}_{2}$ and $\mathrm{O}_{2}$ using $\mathrm{Pd}-\mathrm{Ni} / \mathrm{TiO}_{2}$ catalysts. Phil Trans R Soc 378:20200062

17. Quon S, Jo DY, Han GH, Han SS, Seo M, Lee K (2018) Role of $\mathrm{Pt}$ atoms on $\mathrm{Pd}\left(\begin{array}{lll}1 & 1 & 1\end{array}\right)$ surface in the direct synthesis of hydrogen peroxide: nano-catalytic experiments and DFT calculations. J Catal 368:237-247

18. Han G, Xiao X, Hong J, Lee K, Park S, Ahn J, Lee K, Yu T (2020) Tailored palladium-platinum nanoconcave cubes as high performance catalysts for the direct synthesis of hydrogen peroxide. ACS Appl Mater Interfaces 12:6328-6335

19. Wang S, Lewis RJ, Doronkin DE, Morgan DJ, Grunwaldt J, Hutchings GJ, Behrens S (2020) The direct synthesis of hydrogen peroxide from $\mathrm{H}_{2}$ and $\mathrm{O}_{2}$ using $\mathrm{Pd}-\mathrm{Ga}$ and $\mathrm{Pd}-\mathrm{In}$ catalysts. Catal Sci Technol 10:1925-1932

20. Gu J, Wang S, He Z, Han Y, Zhang J (2016) Direct synthesis of hydrogen peroxide from hydrogen and oxygen over activatedcarbon-supported $\mathrm{Pd}-\mathrm{Ag}$ alloy catalysts. Catal Sci Technol 6:809-817

21. Wang S, Gao K, Li W, Zhang J (2017) Effect of Zn addition on the direct synthesis of hydrogen peroxide over supported palladium catalysts. Appl Catal A 531:89-95

22. Cao K, Yang H, Bai S, Xu Y, Yang C, Wu Y, Xie M, Cheng T, Shao Q, Huang $\mathrm{X}$ (2021) Efficient direct $\mathrm{H}_{2} \mathrm{O}_{2}$ synthesis enabled by $\mathrm{PdPb}$ nanorings via inhibiting the $\mathrm{O}-\mathrm{O}$ bond cleavage in $\mathrm{O}_{2}$ and $\mathrm{H}_{2} \mathrm{O}_{2}$. ACS Catal 11:1106-1118

23. Crombie CM, Lewis RJ, Kovačič D, Morgan DJ, Slater TJA, Davies TE, Edwards JK, Skjøth-Rasmussen MS, Hutchings GJ
(2021) The selective oxidation of cyclohexane via in-situ $\mathrm{H} 2 \mathrm{O} 2$ production over supported Pd-based catalysts. Catal Lett. https:// doi.org/10.1007/s10562-020-03511-6

24. Crombie CM, Lewis RJ, Taylor RL, Morgan DJ, Davies TE, Folli A, Murphy DM, Edwards JK, Qi J, Jiang H, Kiely CJ, Liu X, Skjøth-Rasmussen MS, Hutchings GJ (2021) Enhanced selective oxidation of benzyl alcohol via in situ $\mathrm{H}_{2} \mathrm{O}_{2}$ production over supported Pd-based catalysts. ACS Catal 11:2701-2714

25. Lewis RJ, Ueura K, Fukuta Y, Freakley SJ, Kang L, Wang R, He Q, Edwards JK, Yamamoto MDJ, Hutchings GJ (2019) The direct synthesis of $\mathrm{H}_{2} \mathrm{O}_{2}$ using TS-1 supported catalysts. ChemCatChem 11:1673-1680

26. Kanungo S, van Haandel L, Hensen EJM, Schouten JC, Neira d'Angelo MF (2019) Direct synthesis of $\mathrm{H}_{2} \mathrm{O}_{2}$ in AuPd coated micro channels: an in-situ X-Ray absorption spectroscopic study. J Catal 370:200-209

27. Menegazzo F, Manzoli M, Signoretto M, Pinna F, Strukul G (2015) $\mathrm{H}_{2} \mathrm{O}_{2}$ direct synthesis under mild conditions on $\mathrm{Pd}-\mathrm{Au}$ samples: effect of the morphology and of the composition of the metallic phase. Catal Today 248:18-27

28. Santos A, Lewis RJ, Malta G, Howe AGR, Morgan DJ, Mapton E, Gaskin P, Hutchings GJ (2019) Direct synthesis of hydrogen peroxide over $\mathrm{Au}-\mathrm{Pd}$ supported nanoparticles under ambient conditions. Ind Eng Chem Res 58:12623-12631

29. Wilson NM, Priyadarshini P, Kunz S, Flaherty DW (2018) Direct synthesis of $\mathrm{H}_{2} \mathrm{O}_{2}$ on $\mathrm{Pd}$ and $\mathrm{Au}_{\mathrm{x}} \mathrm{Pd}_{1}$ clusters: understanding the effects of alloying Pd with Au. J Catal 357:163-175

30. Ouyang L, Da G, Tian P, Chen T, Liang G, Xu J, Han Y (2014) Insight into active sites of $\mathrm{Pd}-\mathrm{Au} / \mathrm{TiO}_{2}$ catalysts in hydrogen peroxide synthesis directly from $\mathrm{H}_{2}$ and $\mathrm{O}_{2}$. J Catal 311:129-136

31. Li J, Ishihara T, Yoshizawa K (2011) Theoretical revisit of the direct synthesis of $\mathrm{H}_{2} \mathrm{O}_{2}$ on $\mathrm{Pd}$ and $\mathrm{Au} @ \mathrm{Pd}$ surfaces: a comprehensive mechanistic study. J Phys Chem C 115:25359-25367

32. Freakley SJ, Kochius S, van Marwijk J, Fenner C, Lewis RJ, Baldenius K, Marais SS, Opperman DJ, Harrison STL, Alcalde M, Smit MS, Hutchings GJ (2019) A chemo-enzymatic oxidation cascade to activate $\mathrm{C}-\mathrm{H}$ bonds with in situ generated $\mathrm{H}_{2} \mathrm{O}_{2}$. Nature Commun 10:4178

33. Sankar M, He Q, Morad M, Pritchard J, Freakley SJ, Edwards JK, Taylor SH, Morgan DJ, Carley AF, Knight DW, Kiely CJ, Hutchings GJ (2012) Synthesis of stable ligand-free gold-palladium nanoparticles using a simple excess anion method. ACS Nano 6:6600-6613

34. Edwards JK, Thomas A, Carley AF, Herzing AA, Kiely CJ, Hutchings GJ (2008) $\mathrm{Au}-\mathrm{Pd}$ supported nanocrystals as catalysts for the direct synthesis of hydrogen peroxide from $\mathrm{H}_{2}$ and $\mathrm{O}_{2}$. Green Chem 10:388-394

35. Scofield JH (1976) Hartree-Slater subshell photoionization crosssections at 1254 and $1487 \mathrm{eV}$. J Electron Spectrosc Relat Phenom 8:129-137

36. García T, Agouram S, Dejoz A, Sánchez-Royo JF, TorrenteMurciano L, Solsona B (2015) Enhanced $\mathrm{H}_{2} \mathrm{O}_{2}$ production over Au-rich bimetallic Au-Pd nanoparticles on ordered mesoporous carbons. Catal Today 248:48-57

37. Ouyang L, Tian P, Da G, Xu X, Ao C, Chen T, Si R, Xu J, Han $\mathrm{Y}(2015)$ The origin of active sites for direct synthesis of $\mathrm{H}_{2} \mathrm{O}_{2}$ on $\mathrm{Pd} / \mathrm{TiO}_{2}$ catalysts: interfaces of $\mathrm{Pd}$ and $\mathrm{PdO}$ domains. J Catal 321:70-80

38. Gong X, Lewis RJ, Zhou S, Morgan DJ, Davies TE, Liu X, Kiely CJ, Zong B, Hutchings GJ (2020) Enhanced catalyst selectivity in the direct synthesis of $\mathrm{H}_{2} \mathrm{O}_{2}$ through $\mathrm{Pt}$ incorporation into $\mathrm{TiO}_{2}$ supported AuPd catalysts. Catal Sci Technol 10:4635-4644

39. Wang F, Xia C, de Visser SP, Wang Y (2019) How does the oxidation state of palladium surfaces affect the reactivity and selectivity of direct synthesis of hydrogen peroxide from hydrogen 
and oxygen gases? A density functional Study. J Am Chem Soc 141:901-910

40. Li H, Zheng B, Pan Z, Zong B, Qiao M (2018) Advances in the slurry reactor technology of the anthraquinone process for $\mathrm{H}_{2} \mathrm{O}_{2}$ production. Front Chem Sci Eng 12:124-131

41. Lunsford $\mathrm{JH}$ (2003) The direct formation of $\mathrm{H}_{2} \mathrm{O}_{2}$ from $\mathrm{H}_{2}$ and $\mathrm{O}_{2}$ over palladium catalysts. J Catal 216:455-460

42. Choudhary VR, Gaikwad AG, Sansare SD (2002) Activation of supported Pd metal catalysts for selective oxidation of hydrogen to hydrogen peroxide. Catal Lett 83:235-239
43. Edwards JK, Solsona SE, Landon P, Carley AF, Herzing A, Kiely CJ, Hytchings GJ (2005) Direct synthesis of hydrogen peroxide from $\mathrm{H}_{2}$ and $\mathrm{O}_{2}$ using $\mathrm{TiO}_{2}$-supported $\mathrm{Au}$-Pd catalysts. J Catal 236:69-79

Publisher's Note Springer Nature remains neutral with regard to jurisdictional claims in published maps and institutional affiliations. 